\title{
Investigating the Empathic Skills of Physical Education Teachers
}

\author{
Tolga Şinoforoğlu - Gülfem Sezen Balçıkanlı*
}

Received: September 17, 2019; received in revised form: February 3, 2020; accepted: February 5, 2020

\begin{abstract}
:
Introduction: As one of the most important requirements for healthy communication, empathy is vital in a great many occupations. Various studies have investigated the importance and level of empathy in various occupation groups. One of the leading occupations requiring strong empathic skills is teaching. Teachers need empathy to create an effective learning environment, develop good communication with their students, and understand them well. The current study investigates the empathic skills of physical education teachers to evaluate various variables.

Methods: The research participants comprised 152 physical education teachers in Turkey, 39 women $(25.7 \%)$ and 113 men $(74.3 \%)$, who completed the Interpersonal Reactivity Index (IRI). Descriptive statistical methods and the Kolmogorov Smirnov test were used to determine whether the data were normally distributed. The data were analysed using ranking t-test and correlation methods as well as descriptive statistical models $(\alpha=0.05)$. The total internal consistency coefficient of the scales, measured by Cronbach's Alpha, was .56.

Results: Regarding the IRI scores for the physical education teachers, the highest mean score was for emphatic concern, followed by perspective taking and fantasy. Teaching duration was associated with higher empathic skill scores. Empathic skills were also positively correlated with higher educational level. Finally, the mean fantasy scores were statistically higher for participants who were not training a school team.

Discussion: Physical education courses contribute to the physiological, sociological, psychological, and moral development of students. For this reason, physical education and sports is a compulsory component of the education system from an early age all around the globe. This makes it essential that physical education teachers have appropriate characteristics that they exhibit in their teaching. In the first place, it is necessary to have healthy communication between the physical education teacher and students.
\end{abstract}

\footnotetext{
* Tolga Şinoforoğlu, Kütahya Dumlupınar University, School of Physical Education and Sports, Kutahya, Turkey; tolga.sinoforoglu@dpu.edu.tr

Gülfem Sezen Balçikanlı, Gazi University, Sport Sciences Faculty, Ankara, Turkey; gsezen@gazi.edu.tr
} 


\title{
Acta Educationis Generalis \\ Volume 10, 2020, Issue 1
}

\begin{abstract}
Limitations: The current study gathered data from one specific region in Turkey, from physical education teachers in the city of Kütahya. Consequently, the demographic data were evaluated only for statistically significant variables. Other variables that were not numerically equal, were not investigated.
\end{abstract}

Conclusions: Physical education teachers should adopt an empathic approach to teacher-student relationships. Educational institutions should organise activities to develop these empathic skills in teachers.

Key words: empathy, empathic skills, physical education teachers.

\section{Introduction}

Empathy plays a key role in establishing healthy communication in various professions. Various studies have demonstrated the importance and level of empathy in various occupation groups. One of the leading occupations requiring strong empathic skills is teaching. Teachers need empathy to create an effective learning environment, develop good communication with students, and understand them well.

There are various definitions of empathy. According to Tettagah and Anderson (2007), "teacher empathy is the ability to express concern and take the perspective of a student, and it involves cognitive and affective domains of empathy." Dökmen (2015) defines empathy as putting oneself in someone else's shoes and understanding their feelings and thoughts accurately, while Mehrabian and Epstein (1972) define it as being able to respond to the emotional experience of others. Davies (1980), who considers empathy as multi-dimensional, defines it as the reactions of one person to the observed experiences of another person. For Rogers (1975), empathy is the process of understanding someone else from their perspective, accurately understanding their thoughts, feelings, and conveying them back. Hoffman (1977) identifies three components in empathy: cognition, emotions, and motivation. Empathic relations are necessary for healthy communication.

In education, empathy is important as a tool for establishing healthy communication between educators and students (Ütkür, 2019), and in preparing and implementing educational programs. Empathy is thus a characteristic that individuals aiming to work in education must acquire (Akyol \& Çiftçibaş1, 2005). As teachers' empathic skills increase, they become more likely to understand and respond appropriately to their students. Such teachers feel that their school environment is more positive than those who are unable to understand and respond appropriately to their students (Barr, 2011). In their studies of pre-service teachers' empathy for classroom victims and problemsolving strategies, Tettegah and Anderson (2007) prioritized the importance of empathy in education. They emphasized that teachers with empathic skills are more effective in reducing peer-bullying, aggression, and antisocial behaviours in schools. Closely related to empathic skills, Doll, Song and Siemers (2004) 


\section{Acta Educationis Generalis \\ Volume 10, 2020, Issue 1}

showed that students who find that their teachers are fair and caring, also trust that they will protect them from in-class victimization and intimidation.

Many studies have shown that empathic skills can be improved through education, whether described as empathy training or empathy communication skills (Dökmen, 1990). Physical education teachers that adopt a holistic approach to developing their students in terms of cognitive, perceptual, and psychomotor skills require strong empathic skills.

The dynamic structure of physical education courses means that students may encounter different cases. These could include frequent experience of negative student behaviour like mocking another student, which cannot perform an action during a lesson or a game, always making one student responsible for equipment, always choosing the strongest students in forming teams or groups, deprecating student successes, and mocking losers (Y1ldiran, 2004). An empathic teacher is critical in solving the problems that result from such behaviours. However, if physical education teachers want to develop their students' empathic skills, they must also possess empathic skills themselves in order to provide empathy training.

This study evaluates the empathic skills of Turkish physical education teachers in relation to several factors.

\section{Method}

\subsection{Participants}

The 152 participants were found through convenience sampling under the principle of voluntarism. The sample comprised 39 male (25.7\%) and 113 female (74.3\%) physical education teachers in Turkish city of Kütahya. Table 1 presents demographic data regarding the sample.

\subsection{Measures}

Interpersonal Reactivity Index: IRI

The Interpersonal Reactivity Index (IRI) was used as to measure the empathic inclinations of the physical education teachers. The IRI was developed by Davis (1983) while the Turkish version was made by Engeler (2005). The questionnaire consists of 28 items that form 4 relatively independent subdimensions. The current study included 21 items to measure 3 dimensions (Fantasy, Perspective Taking, and Empathic Concern), which are considered to have the strongest structures. Responses to the statements in the questionnaire were measured on a five-point Likert-type scale $(0=$ It never defines me; $4=$ It defines me). Perspective Taking represents the level of acceptance of others' perspectives (e.g. "I sometimes try to understand my friends better by imagining how things look from their perspective."). Empathic Concern represents the warmth, closeness, interest, etc. that a person has for others and feelings felt for a person in trouble specifically (e.g. "I often have tender, 


\section{Acta Educationis Generalis \\ Volume 10, 2020, Issue 1}

concerned feelings for people less fortunate than I am".). Fantasy represents the ability to feel the same as imaginary characters in books, films, plays, etc. (e.g. "I really get involved with the feelings of the characters in a novel.") (Davis, 1980, 1983). The Cronbach's Alpha values in this study for the three dimensions were $0.80,0.75$, and 0.70 , respectively.

\subsection{Procedure}

The participants voluntarily completed the IRI and demographic form. The researchers evaluated the completed questionnaires to exclude inappropriately completed ones. Normality tests were first conducted on the data using SPSS software. This analysis used descriptive percentages and frequency statistics, assessment of skewness and kurtosis values, and Kolmogorov Smirnov tests. The data were found to have a normal distribution. According to Jondeau and Rockinger (2003), data are considered as normally distributed when the skewness and kurtosis value coefficients of the sub-dimensions vary between +3 and -3 . The overall internal consistency coefficient for the scales, as measured by Chronbach's Alpha, was .56. Further statistical analyses were conducted using complementary statistical models, t-tests, and correlation analysis $(\alpha=0.05)$.

\section{Results}

As Table 1 shows, a majority of participants were men with nearly a third of participants aged 41 years old or above. Nearly all participants were bachelors of physical education colleges or equivalents with only a few having postgraduate degrees. About three-quarters had specialized in team sports at college. Just over one half of them were teaching in secondary schools, with a clear majority in state schools. Nearly two-thirds had gymnasiums in their schools, and most of them were training a school team while nearly three-quarters were also training a non-school team.

Table 1

Demographic information of participants

\begin{tabular}{llrc}
\hline \multirow{3}{*}{ Gender } & Variables & $f$ & $\underline{\%}$ \\
& Female & 39 & 25.7 \\
\multirow{3}{*}{ Age } & Male & 113 & 74.3 \\
& Total & 152 & 100 \\
& 21-25 years & 6 & 3.9 \\
& 26-30 years & 19 & 12.5 \\
& 31-35 years & 28 & 18.4 \\
& 36-40 years & 45 & 29.6 \\
& 41+ years & 54 & 35.5 \\
\hline
\end{tabular}


Volume 10, 2020, Issue 1

\begin{tabular}{|c|c|c|c|}
\hline & Total & 152 & 100 \\
\hline \multirow[t]{3}{*}{ Education level } & Undergraduate & 131 & 86.2 \\
\hline & Postgraduate & 21 & 13.8 \\
\hline & Total & 152 & 100 \\
\hline \multirow[t]{6}{*}{ Work experience } & $1-5$ years & 23 & 15.1 \\
\hline & $6-10$ years & 35 & 23.0 \\
\hline & $11-15$ years & 36 & 23.7 \\
\hline & $16-20$ years & 32 & 21.1 \\
\hline & $21+$ years & 26 & 17.1 \\
\hline & Total & 152 & 100 \\
\hline \multirow[t]{3}{*}{ Bachelor's degree } & $\begin{array}{l}\text { PESC (Phys. ed. and sports college) or } \\
\text { equivalent }\end{array}$ & 147 & 96.7 \\
\hline & Other & 5 & 3.3 \\
\hline & Total & 152 & 100 \\
\hline \multirow{3}{*}{$\begin{array}{l}\text { Undergraduate } \\
\text { specialization }\end{array}$} & Team sports & 112 & 73.7 \\
\hline & Individual sports & 40 & 26.3 \\
\hline & Total & 152 & 100 \\
\hline \multirow[t]{4}{*}{ Level of courses taught } & Primary & 3 & 2.0 \\
\hline & Secondary & 89 & 58.6 \\
\hline & High school & 60 & 39.5 \\
\hline & Total & 152 & 100 \\
\hline \multirow[t]{3}{*}{ School Type } & State school & 130 & 85.5 \\
\hline & Private school & 22 & 14.5 \\
\hline & Total & 152 & 100 \\
\hline \multirow{3}{*}{$\begin{array}{l}\text { Do you train a school } \\
\text { team? }\end{array}$} & Yes & 134 & 88.2 \\
\hline & No & 18 & 11.8 \\
\hline & Total & 152 & 100 \\
\hline
\end{tabular}

Table 2 shows the mean IRI scores. Empathic concern had the highest score whereas the lowest was fantasy.

Table 2

Distribution of scale sub-dimension scores

\begin{tabular}{|c|c|c|c|c|c|c|}
\hline Sub-dimensions & $\frac{\text { Number of }}{\text { items }}$ & $\underline{N}$ & Mean & $\underline{S . D .}$ & Skewness & $\underline{\text { Kurtosis }}$ \\
\hline Perspective taking & 7 & 152 & 3.65 & .537 & .125 & -.014 \\
\hline Empathic concern & 7 & 152 & 3.86 & .547 & -.480 & .428 \\
\hline Fantasy & 7 & 152 & 2.91 & .549 & -.486 & -.372 \\
\hline
\end{tabular}




\section{Acta Educationis Generalis \\ Volume 10, 2020, Issue 1}

As Table 3 shows, IRI dimensions were not correlated with job experience and education level.

Table 3

Correlations of IRI dimensions with education and job experience

\begin{tabular}{|c|c|c|c|c|c|c|}
\hline & & $\underline{J o b}$ & $\frac{\text { Education }}{\text { lovel }}$ & Perspective & Empathic & Fantasy \\
\hline & & & & & & \\
\hline $\mathrm{Job}$ & $\mathrm{R}$ & 1 & & & & \\
\hline experience & $\mathrm{P}$ & 152 & & & & \\
\hline & $\mathrm{R}$ & $.255^{* *}$ & 1 & & & \\
\hline Eaucallon & $\mathrm{P}$ & .002 & & & & \\
\hline & $\mathrm{N}$ & 152 & 152 & & & \\
\hline Perspective & $\mathrm{R}$ & -.113 & -.008 & 1 & & \\
\hline taking & $\mathrm{P}$ & .166 & .920 & & & \\
\hline & $\mathrm{N}$ & 152 & 152 & 152 & & \\
\hline Empathic & $\mathrm{R}$ & .012 & .077 & $.392^{* * *}$ & 1 & \\
\hline $\begin{array}{l}\text { cmpainic } \\
\text { concern }\end{array}$ & $\mathrm{P}$ & .886 & .345 & .000 & & \\
\hline & $\mathrm{N}$ & 152 & 152 & 152 & 152 & \\
\hline & $\mathrm{R}$ & -.118 & .025 & $.202^{*}$ & $.294^{* *}$ & 1 \\
\hline Fantasy & $\mathrm{P}$ & .149 & .762 & .013 & .000 & \\
\hline & $\mathrm{N}$ & 152 & 152 & 152 & 152 & 152 \\
\hline
\end{tabular}

Table 4 shows mean scores for IRI sub-dimensions in relation to training a school team status. The only significant difference was for perspective taking $(\mathrm{p}<0.05)$ in that training a school team was associated with a higher perspective taking score.

Table 4

\begin{tabular}{llllll}
\multicolumn{6}{l}{ Relationship of IRI sub-dimension scores and undergraduate specialization } \\
\cline { 1 - 5 } IRI Sub-dimensions & Variable & $\underline{\text { Mean }}$ & $\underline{\text { S.D. }}$ & $\underline{t}$ & $\underline{P}$ \\
Perspective taking & Team sports & 3.7015 & .52814 & 1.983 & $.049^{*}$ \\
& Individual sports & 3.5071 & .54321 & & \\
Empathic concern & Team sports & 3.8329 & .58223 & -1.055 & .293 \\
& Individual sports & 3.9393 & .43390 & & \\
Fantasy & Team sports & 2.9222 & .54268 & .395 & .694 \\
& Individual sports & 2.8821 & .57315 & & \\
\hline
\end{tabular}




\section{Acta Educationis Generalis \\ Volume 10, 2020, Issue 1}

Table 5 shows IRI sub-dimension scores in relation to a bachelor degree in the given specialization. A significant difference was found for fantasy depending on specialization $(\mathrm{p}<0.05)$.

\section{Table 5}

\begin{tabular}{lccccc}
\multicolumn{6}{l}{ Relationship of IRI sub-dimension scores and training a school team } \\
\cline { 1 - 7 }$\underline{\text { IRI Sub-dimensions }}$ & Variable & $\underline{\text { Mean }}$ & $\underline{\text { S.D. }}$ & $\underline{t}$ & $\underline{P}$ \\
Perspective taking & Yes & 3.6652 & .53770 & .931 & .354 \\
& No & 3.5397 & .53577 & & \\
Empathic concern & Yes & 3.8486 & .55058 & -.754 & .452 \\
& No & 3.9524 & .53227 & & \\
Fantasy & Yes & 2.8689 & .55648 & -2.673 & $.008^{*}$ \\
& No & 3.2302 & .36713 & & \\
\hline
\end{tabular}

\section{Discussion}

Physical education courses contribute to the physiological, sociological, psychological, and moral development of school students. Physical education and sports are compulsory in education systems from an early age, which makes it different from other educational courses. Thus, physical education teachers should be empathetic and show it in their teaching. This requires healthy communication between the physical education teacher and students. The source of healthy communication is to understand the other side and make them feel that you understand them. Physical education teachers should be able to see things from the perspective of students, understand what they feel, and tell it to them. The current study investigated the empathic skills of PE teachers in relation to their educational background and work experience.

The physical education teachers participating in the study had the highest scores for empathic concern. This occurs when an individual exhibits sadness and discomfort from witnessing the sadness of others. Empathic concern reflects interest and sensitivity to others (Davis, 1994). Empathy is crucial for physical education teachers in approaching their students because it includes such aspects as concern for people, protecting them, and pitying them.

Perspective taking involves taking the perspective of others. According to Hoffman (1990), perspective taking is the pre-requisite for understanding an individual in need, cognitively and affectively, and responding appropriately. Physical education teachers need strong perspective taking skills.

The participants in this study scored lowest for fantasy. This comprises such skills as being able to think and dream about events likely to happen to them regularly, being able to put themselves in the place of a character in a play, film, or book, and being interested in the feelings of fictional characters. The teachers 


\section{Acta Educationis Generalis \\ Volume 10, 2020, Issue 1}

in this study demonstrated medium empathic skills (Table 2), which indicates a need to implement empathy training programs to improve their level. The way to raise healthy individuals requires healthy communication. Given that empathy is a skill that can be developed through education, teachers should be trained from the very beginning of their undergraduate education to use empathy, which is in line with the findings that both experience and education levels are not associated with higher empathic skills (Table 3). Similarly, Rogers (1975) noted that empathic skills develop through education as well as from empathic people. That is, empathic skills can be developed through education programs for candidate teachers while they are still students (Sezen-Balçıkanl1, 2009).

In perspective taking, teachers who were teaching team sports achieved higher scores than those teaching individual sports (Table 4). Sport interactions particularly rely on coordinating movements in team sports. They, therefore, require the skill to understand the play from multiple sources. For example, a player should predict what their team mate will do (Shields, 1994). On the other hand, teachers who were not training a school team acieved significantly higher IRI scores in fantasy than those who did (Table 5). For empathic concern, those training a school team achieved slightly, but non-significantly higher scores. This suggests that competition prevents empathy since an empathic manner is not appropriate for competitive environments.

When people are taught communication skills and shown their prejudice and fears, they can easily empathize with others, develop a trust for rehabilitative skills, and become a rehabilitative being for others (Davis, 2005). Thus, strong empathic skills are important for physical education teachers for establishing good relationships with their students. Aktaş and Sezen-Balçıkanlı (2018), for example, found that empathy affects social problem-solving skills of physical education teachers. This highlights the need for empathy education while preparing for the teaching occupation and while working as a teacher during inservice training. In short, physical education teachers should care about their relationships with their students in terms of empathic understanding. They should also more frequently undertake activities to improve their empathic skills.

\section{Conclusions}

This study examined the empathic skill levels of 152 physical education teachers in Turkey in relation to several factors as measured by a three-dimension version of the Interpersonal Reactivity Index (IRI) questionnaire. The findings indicate that the participants achieved the highest scores in empathic concern, followed by perspective taking and fantasy. Both teaching experience and educational level were positively associated with stronger empathic skills. Teachers who did not train a school team had significantly higher scores for Fantasy.

The current study was conducted in one particular city in Turkey. Future studies could investigate other variables affecting IRI scores that were excluded from the current study. This could include evaluating the empathic skills of teachers in 


\section{Acta Educationis Generalis \\ Volume 10, 2020, Issue 1}

different cities or those working in private and state schools, the relationship between empathic skills and specific sport branches, or the differences between physical education teachers and other teachers.

Certain recommendations can be made based on the presented findings as on how empathy can be developed during pre-service and in-service education of physical education and sports teachers. First, pre-service teachers must be provided with opportunities to experience empathy themselves during their training courses. They should also certainly focus on how to develop empathy with their future students. Secondly, in-service teachers who are experiencing empathy and emotions related to it need to bring these cases into in-service training seminars to teach about practical solutions to problems related to a lack of empathy.

\section{References}

Aktaş, İ., \& Sezen-Balçıkanlı, G. (2018). The levels of empathy and social problem solving skills of physical education and sports teacher candidates. i-manager's Journal on Educational Psychology, 11(4), 814.

Akyol K. A., \& Çiftçibaşı K. H. (2005). Okul öncesi öğretmen adaylarının empatik beceri düzeylerinin belirlenmesi. Eurasian Journal of Educational Research, 21, 13-23.

Barr, J. J. (2011). The relationship between teachers' empathy and perceptions of school culture. Educational Studies, 37(3), 365-369.

Davis, C. M. (2005). Empati nedir, empati öğretilebilir mi? İnönü University Journal of Ë̆itim Bilimleri Fakültesi, 6(9), 77-88.

Davis, H. M. (1980). A multidimensional approach to individual differences in empathy. JSAS Catalog of Selected Documents in Psychology, 10, 85.

Davis, H. M. (1983). Measuring individual differences in empathy: evidence for a multidimensional approach. Journal of Personality and Social Psychology, 44(1), 113-126

Doll, B., Song, S., \& Siemers, E. (2004). Classroom ecologies that support or discourage bullying. In D. L. Espelage, \& S. M. Swearer (Eds.), Bullying in American Schools: A Social Ecological Perspective on Prevention and Intervention (pp.161-183). New Jersey: Lawrence Erlbaum and Associates.

Dökmen, Ü. (1990). Yeni bir empati modeli ve empatik becerinin iki farklı yaklaşımla ölçülmesi. Psikoloji Dergisi, 7(24), 42-50.

Dökmen, Ü. (2015). Sanatta ve günlük yaşamda iletişim çatışmaları ve empati (53 ${ }^{\text {rd }}$ edition). İstanbul: Remzi.

Engeler, A. (2005). Psikopati ve antisosyal kişilik bozukluğu (Unpublished doctoral thesis). İstanbul: İstanbul University, Institute of Forensic Medicine Social Sciences Department. 


\section{Acta Educationis Generalis \\ Volume 10, 2020, Issue 1}

Hoffman, M. L. (1990). The contribution of empathy to justice and moral judgment. In N. Esinberg, \& J. Strayer (Eds.), Empathy and Its Development (pp. 47-80). New York: Cambridge University Press.

Hoffman, M. L. (1977). Empathy, its development and prosocial implications. Nebraska Symposium on Motivation, 25, 169-217.

Jondeau, E., \& Rockinger, M. (2003). Conditional volatility, skewness, and kurtosis: existence, persistence, and comovements. Journal of Economic Dynamics \& Control, 27, 1699-1737.

Köksal-Akyol, A., \& Koçer-Çiftçibaşı, H. (2005). Okul öncesi öğretmen adaylarının empatik beceri düzeylerinin belirlenmesi. Eurasian Journal of Education Research, 2, 13-23.

Mehbarian, A., \& Epstein, N. (1972). A measure of emotional empathy. Journal of Personalty, 40, 523-543.

Rogers, C. R. (1975). Empathic: An unappreciated way of being. The Counseling Psychologist, 5(2), 2-10.

Sezen-Balçıkanlı, G., \& Yıldıran, İ. (2018). Elit salon hokeyi oyuncularında empatik beceri ile prososyal davranışlar arasındaki ilişki. Gazi Beden Eğitimi ve Spor Bilimleri Dergisi, 23(1), 1-8.

Sezen-Balçıkanlı, G. (2009). Fair play and empathy: A research study with student teachers. Journal of US-China Public Administration, 6(4), 7984.

Shields, L. L. D., \& Bredemeier, L. J. B. (1994). Character development and physical activity. USA: Human Kinetics.

Tettegah, S., \& Anderson, C. J. (2007). Pre-service teachers' empathy and cognitions: Statistical analysis of text data by graphical models. Contemporary Educational Psychology, 32(1), 48-82.

Ütkür, N. (2019). Determination of the empathy levels of prospective classroom teachers: An example of the life skills teaching course. Acta Educationis Generalis, 9(3), 89-104. https://doi.org/10.2478/atd-2019-0015

Yıldıran, İ. (2005). Fair play eğitiminde beden eğitiminin rolü. Gazi Beden Eğitimi ve Spor Bilimleri Dergisi, 10(1), 3-16. 